\title{
Too Little - Or - Too Much Competition? Integrating Legal And Relationship Marketing Strategies To Manage Market Entry Adversity
}

De Vee E. Dykstra, (E-mail: ddykstra@usd.edu), University of South Dakota Lynn Muller, (E-mail: lmuller@usd.edu), University of South Dakota

\begin{abstract}
In the deregulated, yet highly regulated environment of the telecommunications industry, a rural telephone cooperative transformed itself into a successful integrated telecommunications company. Managing local political and legal environments along with using relationship marketing tactics implemented cross-functionally, this Midwestern company challenged incumbent monopolies for market share. While the company spent more than one year acquiring legal permission to access the market and another year building its fiber optic telecommunications network, it also "constructed" relationships with community leaders, politicians, media outlets, and thousands of residents. Its monopoly competitors utilized state laws and the legal process in an attempt to prevent the Midwestern company's entry into the market. Interestingly, the competitors ignored the necessity of relationship marketing and by the time the Midwestern company's first client was connected, it had a waiting list of eager new consumers. This case chronicles the actions taken to achieve the Midwestern company's major accomplishments and expansion and is appropriate for use in a graduate Business and Society, or Business, Government and Society course.
\end{abstract}

\section{INTRODUCTION}

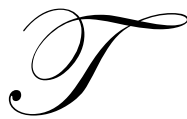

his case presents a business' expansion strategies which integrate law and marketing concepts. In particular, legal issue management and relationship marketing tactics implemented crossfunctionally by a telecommunications company resulted in the business' successful expansion. The case is based upon actual events but contains modifications to ensure company confidentiality. It was developed primarily through research of publicly available information. The case presented is an excellent example of how legal maneuvering and relationship marketing can be used by an industry newcomer to successfully challenge incumbent monopolies for market share.

Part I of this article contains the case study along with questions which may be provided to or asked of students. Part II is the teaching note which includes the case synopsis, teaching objectives, potential uses of and suggested approaches to teaching the case, and discussion of actual events.

\section{PART I: THE CASE SUDY - DAKOTA DIGITAL SERVICE}

George Smythe, Vice President of Marketing for Dakota Digital Service (DDS), a rural telephone and cable television cooperative, was having a bad morning. He had just returned from a seven day New Year's cruise to a stack of phone messages sitting on his desk, every one of them demanding attention. 
A local city commissioner had called to complain about property damage discovered at his church caused by DDS construction of its new fiber optic cable network. The company's sales manager had called to ask if the new pricing discounts had been approved. The local newspaper wanted to know the status of DDS's proposed print ad campaign. The company's supervising engineer had decided to postpone any further construction until the weather improved. The head of DDS's customer service had notified him that all new DDS customers would probably have to switch their phone numbers if they chose DDS service. A potential customer had called to complain that another DDS construction crew had damaged her tomato plants while working in the utility right-ofway in her backyard. And, Smythe had to prepare for a 1pm meeting with Sara Adams, the company's attorney, and Bill Jones, the company's president. The meeting was scheduled to discuss strategies to address expected legal and marketing issues related to DDS's expansion goals.

Smythe had to choose - which phone call to return first? Which problem to solve first? When would he read through the list of legal issues and think about marketing strategies? And it was already $10 \mathrm{am}$.

\section{History Of The U.S. Telecommunications Industry}

The American telecommunications industry has changed radically in the last century. Major technological advances coupled with corresponding shifts in governmental policies triggered these changes. The first phase began with Alexander Graham Bell's invention of the telephone in 1876. The new telephone industry grew rapidly with the development of thousands of small local telephone exchanges. During the first half of the $20^{\text {th }}$ century, however, one company gained market dominance - American Telephone \& Telegraph (AT\&T). During this time the national telephone network was an unregulated monopoly owned and operated by AT\&T.

When Congress passed the Communications Act of 1934, AT\&T controlled two-thirds of the local phone market and all of the long distance market (1994 Congressional Quarterly Almanac). The 1934 Act ushered in the second phase of the industry's history. The federal government protected this monopoly in order to promote affordable universal telephone service. State regulation allowed a guaranteed rate of return on telephone infrastructure investment and service. In exchange for that guaranteed profit, AT\&T offered uniform price and quality.

But, there were hidden costs attached to this policy. First, regulated prices did not reflect true costs. Artificially high long distance rates subsidized the low prices of high-cost local service. Businesses using bulk telephone services subsidized residential services where the user made perhaps only one or two daily phone calls. Second, such regulation provides no incentives for technological advances.

The third chapter of the industry's history began as AT\&T's anti-competitive practices caught the attention of the U.S. Department of Justice, which filed an antitrust lawsuit against AT\&T in 1974. The Department of Justice alleged that AT\&T had "violated the Sherman Act by using its market power to bar entry into markets by other corporations." (U.S. District Court, 1997) The lawsuit was finally settled in a 1982 consent decree, dividing AT\&T into unregulated, competitive long distance service, offered by the former parent company, and regulated local service, offered by seven regional Bell operating companies, including US West. In the meantime, the unregulated telecommunications video and data transmission technologies were exploding. Voice transmission via telephone's copper wire and video transmissions via TV cable were converging. People wanted "communications power" - not telephone power or television power.

These technology developments and consumer demands were destroying the artificial distinction between regulated voice transmission and unregulated video and data transmission. After several failed attempts, Congress finally acted, shifting federal policy "from one largely protecting monopoly to one of promoting competition" (Brock \& Katz, p.104). The 1996 Telecommunications Act also allowed local telephone companies to move into competitive, unregulated markets such as video and data transmission as soon as there was proven competition in the local telephone market (1995 Congressional Quarterly Almanac). 
Much of the industry's subsequent focus has been on these competitive services. Some entrepreneurs saw a tremendous opportunity in the local telephone markets, where $\$ 1$ billion in phone calls are made annually (Shaffer, 1998). Most of these entrepreneurs were content to access or "rent" space on the incumbent monopoly's infrastructure. However, faced with the opportunity to meet exploding consumer demands, some companies decided that long-range success depended on building a completely separate, state-of-the-art fiber optic network, providing high-speed voice, video, and data transmission on an independently owned system. One company was Dakota Digital Service (DDS), a small town utility company located in DeSmet, South Dakota.

\section{An Integrated Telecommunications Company}

Founded in 1902, DDS began as a typical rural telephone co-operative, providing basic local phone service to farm communities in eastern South Dakota. DDS owned the "last mile" - the copper wire traveling from the main telephone switch office to individual customers. DDS connected with the national AT\&T monopoly through its switch, linking its customers to the rest of the world. However, DDS's management was not content, especially with the government regulated rate of return which, although guaranteed, was perennially low. Moreover, DDS's customers wanted the same kinds of new telecommunications services available to their urban neighbors. Consequently, DDS began cable television service in 1982. DDS operations managers bridged the gap between regulated and unregulated services, between voice transmission and video transmission.

In 1995, through the acquisition of the Internet company named DakNet, DDS became the largest Internet Service Provider (ISP) in the state of South Dakota. Assets were now over $\$ 44$ million. ISPs were totally unregulated, allowing DDS to enter the new, hugely profitable data transmission business. DDS also purchased a long-distance company, FairLine, and a business data services company, CoData. DDS was now home to an oldfashioned state and federally regulated voice transmission monopoly, a profitable locally regulated cable/fiber optic transmission monopoly, and New Age unregulated businesses in computer technology and data transmission. DDS had grown to 160 employees and 25,000 customers serving 17 South Dakota communities. Its revenues had grown to just over $\$ 4$ million with nearly $\$ 2$ million in net cash flow from operations. The company did, however, experience a net loss a result of its recent acquisition activities. Exhibit 1 displays two years of DDS financial data.

Exhibit 1: DDS Financial Statements

\begin{tabular}{|l|c|c|}
\hline \multicolumn{1}{|c|}{ Revenues } & DDS Income Statement & $\mathbf{1 9 9 6}$ \\
\hline Local Network & $1,221,788$ & $\$ 1,058,667$ \\
\hline Network Access & $4,176,695$ & $1,996,301$ \\
\hline Long Distance Network & $3,478,721$ & $1,300,512$ \\
\hline Cable Television Service & $1,517,028$ & -- \\
\hline Computer Network Sales & $1,788,104$ & 72,447 \\
\hline Internet Service & $1,021,344$ & 406,446 \\
\hline Other & 25,312 & $2,406,766$ \\
\hline Costs and Expenses & & -- \\
\hline Plant Operations & $4,082,624$ & $, 434,416$ \\
\hline Cost of Goods Sold & $1,465,885$ & 500,802 \\
\hline Depreciation and Amortization & $3,448,109$ & $1,817,869$ \\
\hline Customer & $1,465,735$ & 863,639 \\
\hline General and Administrative & $4,215,257$ & $8,023,492$ \\
\hline Other Operating Expenses & 810,041 & \\
\hline Total Operating Expenses & $15,487,651$ & 309,982 \\
\hline Other Income and (Expenses) & & $(723,778)$ \\
\hline Interest and Dividend Income & 276,204 & $(413,796)$ \\
\hline Interest Expense & $(1,122,807)$ & $(335,946)$ \\
\hline Net Other Income and (Expenses) & $(846,603)$ & $(\mathbf{\$ 1 6 0 , 2 3 4 )}$ \\
\hline Loss Before Income Taxes & $(118,475)$ & \\
\hline NET LOSS & $\mathbf{( \$ 2 , 4 8 6 , 7 8 7 )}$ & \\
\hline
\end{tabular}




\begin{tabular}{|l|c|c|}
\hline \multicolumn{2}{|c|}{ DDS Balance Sheet } & \\
\hline Assets: & & \\
\hline Current Assets & $10,261,743$ & $6,040,903$ \\
\hline Investments and Other Assets & $8,369,883$ & $14,441,104$ \\
\hline Property, Plant and Equipment (net) & $25,408,266$ & $\mathbf{2 3 , 5 0 4 , 8 7 5}$ \\
\hline & & \\
\hline Total Assets & $\mathbf{4 4 , 0 3 9 , 8 9 2}$ & \\
\hline & & $1,594,782$ \\
\hline Liabilities and Stockholders' Equity: & & $15,338,395$ \\
\hline & $6,921,786$ & 159,482 \\
\hline Current Liabilities & $29,200,469$ & $17,092,659$ \\
\hline Long-term Debt & 113,565 & $1,172,000$ \\
\hline Deferred Credits & $36,235,820$ & 26,185 \\
\hline Total Liabilities & & 4732723 \\
\hline & & 481308 \\
\hline Preferred Stock & -- & $\underline{6,412,216}$ \\
\hline Common Stock & $8,523,870$ & \\
\hline Other Stock/Capital & $1,285,681$ & \\
\hline Retained Earnings (Deficit) & -2005479 & $\mathbf{2 3 , 5 0 4 , 8 7 5}$ \\
\hline Total Stockholders' Equity & $\underline{7,804,072}$ & \\
\hline & & \\
\hline Total Liabilities and Stockholders' & & \\
Equity & $\mathbf{4 4 , 0 3 9 , 8 9 2}$ & \\
\hline
\end{tabular}

Throughout this evolution, DDS remained faithful to its original mission of a century earlier - providing superior customer service. DDS believed that its culture of relationship marketing - a practice that predated academic theorizing - could beat entrenched telephone and cable TV monopolies. To help improve shareholder return, in 1998, DDS announced a business plan that exploited deregulation. It proposed building a state-of-the-art fiber-optic network in dozens of rural communities. This network would connect with its newly installed Lucent Technologies 5ESS switch, a technology generally found only in highly concentrated urban markets. DDS's network would compete with incumbent telephone and CATV companies on price and service. Furthermore, DDS's network would offer a range of new services - from calling waiting to broadband Internet - previously unavailable to the small markets of the Upper Midwest. These services would be offered in a consumer "menu," with each additional service earning a "package" discount.

The DDS plan echoed a century of rural entrepreneurial progress. The indigenous peoples of the Missouri River Basin followed the early buffalo trails and the hardy pioneers who settled the Midwestern plains entered that frontier on a line of sight. Railroads later traced those same trails, bringing thousands of hopeful immigrants to the land. DDS saw itself as the heir to that history. Its fiber optic network would be an extension of that "transportation" system. DDS desired entering this frontier at the speed of light. At 186,262 miles per second, fiber optics literally makes distance disappear and removes the remoteness of the Midwest.

This message was particularly attractive to a region famous for its remoteness. DDS argued that the Great Plains was "invented" for the telecommunications revolution and positioned itself as the futuristic advocate for all rural Americans, the "have-nots" left behind by the industry's exponential growth. DDS' plan was to continue expansion throughout South Dakota, then to the remainder of the upper Midwest. "One community that eagerly welcomed DDS was Huron, South Dakota. A town of less than 15,000 inhabitants, Huron was the largest community to date in DDS's proposed construction plan. DDS was eager to begin its expansion into Huron, SD.

\section{Barriers To Entry}

DDS faced five enormous barriers to entry in Huron. First, local, state and federal regulatory requirements had to be met before construction could even begin. Even though the 1996 Act was a major overhaul to the federal 
requirements, the telecommunications industry remained highly regulated. For example, even though Congress passed the 1992 Cable Act with the intent to rely on the marketplace to ensure cable operators would continue to expand their capacity and program offerings, and to ensure cable operators did not have undue market power; several regulatory requirements still had to be met. Additionally, the Cable Act delegated primary regulatory authority to state and local authorities and required all new cable operators to acquire a franchise, compensate property owners for use of and damage to rights of way, be subject to any assessed local franchise fees, improve quality of customer service, and file several forms and reports (Federal Communications Commission, 2000). States and municipalities responded by passing laws and ordinances with which cable operators must comply. South Dakota delegated the majority of its franchise authority to the municipalities. Exhibit 2 contains the text of the South Dakota statute.

\section{Exhibit 2: South Dakota Codified Law, (S.D.C.L. \$9-35-18)}

9-35-18. Regulation of CATV systems by ordinance. Notwithstanding the provisions of $\S 9-35-3$, all municipalities shall have exclusive jurisdiction by ordinance to regulate, prohibit, and consent to the construction, installation, operation, and maintenance of CATV systems within their corporate limits.

In Huron, companies must complete several steps, one of which was to acquire a franchise. This process involves preparing a proposal to be presented to a city's Franchise Committee for review. The proposal must address the company's technological capabilities, financial stability, proposed expansion plans, plans for compliance with federal and state customer service standards, proposed product/service offerings and fees, and include a map of underground equipment proposed locations. Once the proposal is presented to the committee, the approval process involves several more steps including public hearings, recommendation of the committee and concluding with a city council vote either for or against granting the franchise. Sara Jones estimates this process would take a minimum of eight weeks if there is no controversy or delay. However, the S.D. cable franchise statutes were unclear about whether municipalities had the "exclusive power" to grant cable franchises, or whether grants of franchises could be challenged with a public vote.

Monopolies were permissible prior to enactment of the 1996 Act and consumers wanted access to cable TV so any question of whether a city council had exclusive power was not addressed. Additionally, South Dakota law required cable franchises to be financially stable and technologically qualified. The incumbent monopolies were well aware of the lack of clarity in and qualification standards required by the law. With the 1996 Act's goal of increasing competition, the incumbent monopolies were not only in need of but, also in a position to use varying interpretations of S.D. law to force the issue and delay or maybe even stop DDS's expansion efforts. As a result, the incumbents began to "condition" the community's opinion and indicated that should the Huron city council approve a franchise for DDS, they would begin the process of bringing the franchise to a public vote.

Second, the incumbent telephone and cable monopolies had no intention of losing customers without counteroffers and attacks. The only local telephone company in Huron, US West (now Qwest), was a tightly controlled monopoly with more resources than DDS. US West served 14 states, including the 35 largest communities in South Dakota, and had 30 million customers nationwide, with sales revenues approaching \$11 billion. At the same time, other telecommunications services, such as cable TV, were also tightly controlled with little or no competition. Huron Cable Company (HCC) had the community's lone cable franchise.

HCC began in 1979 and initially offered 20 channels. The company slowly expanded to approximately 30 channels in the mid-1980s. By 2000 it offered 34 stations, three of which were premium channels (HBO, Cinemax and The Movie Channel). A survey conducted in 2005 showed that Huron and Pierre were the only two major communities in the eastern half of South Dakota that did not offer pay-for-view alternatives. HCC eliminated its basic \$9 service and was charging approximately \$24 per month for its cable package. After DDS announced its expansion intentions, HCC mentioned during its franchise renewal hearing with the city its plans to install a network similar to DDS's proposed system. However, HHC's discussions focused primarily on its accomplishments in the 
past and not on its plans for the future. Its only statement about future operations was that HHC would need to reduce support for community activities it was forced to compete.

Third, millions of dollars would be needed to build such systems. This project would be built to serve not only Huron, but also the east central portion of the state. Estimated construction costs for a project this size would be \$50-\$55 million. Market development, marketing, and implementation would result in a significant financial investment as well. This project's total investment could only be secured with a demonstration of success in the marketplace.

Fourth, installation of the new fiber optic cable network, capable of carrying voice, video and data, would require skilled labor and supplies not readily available in the upper Midwest. In fact, such a system was so new that it would literally be beta tested on site rather than in a laboratory or controlled environment.

Last, any customers choosing DDS services would have to accept a variety of inconveniences. These included changing phone numbers. US West had not yet begun provision of "local number portability" (LNP). The 1996 Telecommunications Act required that incumbent providers allow customers to keep their phone numbers when they changed to another company. However, the switching technology, while available, was not fully installed throughout the regional networks, and clearly, the lack of LNP was a significant obstacle to competition (Reinke, 1998). Additionally customers would have to deal with fiber optic installation construction on their property and they would need to complete numerous sales forms required by law. DDS was concerned that customer dissatisfaction with the incumbent service providers might easily be outweighed by fear of uncertainty and change.

\section{Huron Community Demographic Profile}

Huron is the ninth largest city in South Dakota with a population of 11,893. There are 5,263 households with an average household size of 2.18 persons. (Note: some persons do not live in households, e.g., persons living in long term care facilities.) Huron is an elderly community with 21 percent of the population 65 years of age or older (compared to S.D. at 14.3\%). As a result the median age of the Huron population is 40.3 years compared to the S.D. population's median age of 35.6 years. The Huron population includes a fair number of retirees because the city attracts retired people from the smaller surrounding communities. Huron does provide good health care and entertainment opportunities for the elderly community. The South Dakota population is not rich; median household income is only $\$ 35,282$. Huron, due to its elderly population, has an even lower household income, $\$ 29,097$. However, household earning averages are higher. Average earnings per household are $\$ 43,382$ in South Dakota, and $\$ 39,190$ in Huron.

Even though Huron is an elderly community, the majority (62.4\%) of the Huron population age 16 and older is employed. Most work in the management, professional and related occupations $(30.1 \%)$. Exhibit 3 provides the percent of persons employed by occupation for S.D. and Huron.

Exhibit 3: Percent Employed by Occupation (U.S. Bureau of the Census, 2000)

\begin{tabular}{|c|c|c|}
\hline Occupation & South Dakota & Huron \\
\hline Management, professional, and related occupations & $32.6 \%$ & $30.1 \%$ \\
\hline Service occupations & $15.6 \%$ & $18.3 \%$ \\
\hline Sales and office occupations & $26.5 \%$ & $20.2 \%$ \\
\hline Farming, fishing, and forestry occupations & $1.9 \%$ & $1.9 \%$ \\
\hline Construction, extraction, and maintenance occupations & $9.1 \%$ & $7.9 \%$ \\
\hline Production, transportation, and material moving occupations & $14.2 \%$ & $21.6 \%$ \\
\hline
\end{tabular}


Huron is geographically located in Beadle County in east-central South Dakota farming country. It does industrial structure is heavily reliant on agriculture. In fact, the majority of the manufacturing industry is agricultural related. In addition, like much of South Dakota, most businesses are considered small. In fact, Huron has only 2 business establishments with 250 or more employees. Exhibit 4 provides the number of business establishments by industry and by employment size.

Exhibit 4: Businesses by Industry and Size (U.S. Bureau of the Census, 2004)

\begin{tabular}{|l|c|c|c|c|c|c|c|}
\hline Industry & Total & $\mathbf{1 - 4}$ & $\mathbf{5 - 9}$ & $\mathbf{1 0 - 1 9}$ & $\mathbf{2 0 - 4 9}$ & $\mathbf{5 0 - 2 4 9}$ & $\mathbf{2 5 0 +}$ \\
\hline Total & 579 & 309 & 132 & 73 & 48 & 15 & 2 \\
\hline Forestry, fishing, agriculture support, hunting & 5 & 4 & 0 & 0 & 1 & 0 & 0 \\
\hline Utilities & 4 & 2 & 0 & 1 & 0 & 1 & 0 \\
\hline Construction & 63 & 38 & 15 & 8 & 2 & 0 & 0 \\
\hline Manufacturing & 29 & 12 & 2 & 4 & 6 & 5 & 0 \\
\hline Wholesale trade & 29 & 9 & 4 & 7 & 6 & 0 & 0 \\
\hline Retail trade & 99 & 42 & 30 & 19 & 4 & 4 & 0 \\
\hline Transportation \& warehousing & 29 & 21 & 6 & 1 & 1 & 0 & 0 \\
\hline Information, finance., insurance \& real estate & 84 & 60 & 11 & 5 & 8 & 0 & 0 \\
\hline Professional, scientific, \& tech services & 28 & 18 & 8 & 1 & 0 & 1 & 0 \\
\hline Health care and social assistance & 53 & 19 & 17 & 5 & 8 & 2 & 2 \\
\hline Other services & 147 & 77 & 36 & 20 & 12 & 2 & 0 \\
\hline Other industries & 9 & 7 & 0 & 2 & 0 & 0 & 0 \\
\hline
\end{tabular}

\section{The Work Ahead}

Smythe, Adams and Jones' $1 \mathrm{pm}$ meeting to develop strategies addressing the legal concerns and discuss utilizing relationship marketing strategies during the preconstruction and construction phases of the Huron expansion project was looming.

The group had to develop strategies to combat HCC's potential legal maneuvers to block their expansion into Huron. What could they do to prevent a public vote? What strategies could Smythe and his staff develop to combat HCC's efforts? Additionally, Smythe had to create an entire new marketing strategy or set of strategies to tackle not one, but two, local monopolies. He believed that market domination meant a DDS market share of not less than $60 \%$. This was George's ultimate goal for DDS.

In a company like DDS, financially and administratively challenged, limited resources are often allocated according to managers' persuasive strengths. "Important decisions involving resources are made through bargaining and deal-making. So project managers who wish to succeed must learn to use the [internal] political system to their advantage" (Pinto \& Kharbanda, 1995). And Smythe did, successfully arguing that all DDS functions were essentially marketing functions. This argument not only unleashed necessary resources, it also resulted in authorization for Symthe to impose a cross-functional structure on the company's competitive and expansion efforts, coordinating marketing with construction and engineering, the sales force, the legal department and the accounting division. Smythe was in control of $\$ 30,000$ for marketing and market development in the Huron area only. While the $\$ 30,000$ seems small, when one considers the population and business base in the Huron the amount was deemed appropriate for marketing to that base. Exhibit 5 contains the projected marketing budget developed for this project. 
Exhibit 5: DDS Marketing Budget

\begin{tabular}{|c|c|}
\hline Local Advertising Budget & $\mathbf{1 8}$ Month Period \\
\hline Newspaper (includes display ads) & $\$ 14,000$ \\
\hline Radio & 2,000 \\
\hline Special Events & 7,000 \\
\hline Direct Mail & 3,000 \\
\hline Premium Giveaways & 1,000 \\
\hline Store Advertising and In-store Signage & 3,000 \\
\hline Total Marketing Budget* & $\$ 30,000$ \\
\hline
\end{tabular}

An important issue Smythe needed to consider when developing his strategy was concern that consumers in Huron wanted choices but that they would not understand the full menu of options DDS would offer.

Construction would begin in spring 2006 with an estimated cost of $\$ 55$ million for the fiber-optic expansion into the eastern portion of South Dakota. A spring start date was due to anticipated weather related concerns. Snow and ice during the early construction phase would cause delays. It was estimated it would take between 12 and 15 months to complete the project once initiated. This would need to be considered as Smythe developed marketing strategies to maintain customer interest and create community opinion conducive to DDS's expansion into Huron. This consideration is also important to Adams as she begins the franchise proposal and approval process.

\section{PART II: TEACHING NOTES}

DDS is a small rural telecommunications company, providing basic local phone service with an entrepreneurial spirit. It expanded by providing new telecommunications services including long distance, video transmission, Internet service, and business data services. The company operated in the regulated and unregulated segments of the telecommunications industry which were dominated by service segment monopolies. DDS had legal, marketing, and potential financial issues to address and believed that a contemporary market strategy, called "relationship marketing," would help ensure its success. Relationship marketing, used cross-functionally by this small integrated telecommunications company, was the key to winning majority market share from two monopoly competitors. The legal department was successful in negotiating the legal and governmental processes to ensure efficiency in the franchise application and approval process. This case also deals with the benefits deregulation has brought to consumers and the significant competitive issues in the telecommunications and cable industries.

\section{Teaching Objectives}

The educational objectives for a graduate Business and Society, or Business, Government and Society course, are for the student to:

1. appreciate the complex interactions among business, government and society;

2. describe the seven key environments affecting business today;

3. demonstrate an understanding of the importance of integrating and managing legal, governmental and relationship marketing concepts as part of the business strategic management process in a highly regulated industry;

4. articulate the government's regulatory influence on business;

5. provide a perspective of the issues arising out of deregulation; and

6. continue to develop critical thinking and problem solving skills.

\section{Potential Uses Of The Case And Teaching Suggestions}

This case is designed to stimulate class discussion by raising questions and emphasizing multiple or opposing perspectives on legal and marketing issues. There are four basic ways to use the case. 
First, it can be assigned as a reading. The case is of moderate length and reading it adds additional insight into the concepts of the countervailing forces and stakeholder models of the BGS relationship, seven key environments of business, governmental regulation and deregulation, strategic management and relationship marketing. If the case is used as a reading, students can be tested on it using the discussion questions found in this teaching note.

Second, the case can be used for class discussion. There are three primary methods by which this can be accomplished.

1. The instructor can lead the discussion,

2. One student could be assigned the case and either present a viewpoint or strategy to the class or act as a discussion leader, or

3. Two or three students can be assigned to debate the case, presenting alternative strategies or positions on the major issues in the case. This is a very effective way to encourage lively debate and discussion. Students tend to build upon and learn from the alternative strategies presented.

Third, the case can be assigned to student teams which would develop over the semester a comprehensive strategic plan incorporating legal and marketing strategies. The teams would be required to prepare and make an indepth presentation of their strategic plan to a panel of local business experts. The students thrive on the competition aspect of this alternative approach.

Fourth, this case provides an interesting possibility for role playing. The two major roles would involve two teams, one with a DDS representative and the other with an HCC representative. Groups would be formed to develop responses to the case's major issues, and to develop counter strategies for possible or anticipated actions initiated by the opposing team. This method of teaching the case enhances student's critical thinking development.

This case is interesting primarily to the graduate business student, though undergraduate business students also enjoy the case. The student will find the case to be an interesting introduction to the concepts of strategic management and corporate public policy, antitrust law, the business, government, and society relationship, and customer relationship marketing. It is also useful to introduce the student to the importance of integrating the functional areas of marketing and law when creating business strategies. Students are required to understand marketing concepts and potential uses of relationship marketing for purposes of shaping community opinion and consumer education. The case also provides an excellent and clear example of how a totally integrated marketing communications and strategic management of legal issues can be developed to achieve strategic goals. Thus, this case would also be useful in a strategic marketing management graduate course.

Graduate students can be challenged to elicit detailed strategies and implementation plans for managing legal challenges, media theme development and selection, and budgetary constraints. These more challenging requirements are illustrated in this teaching note. Students could be tasked with the following:

1. develop strategies DDS could use to garner early city franchise approval for future expansion efforts;

2. identify marketing and legal research needs and develop a basic research agenda;

3. developing a comprehensive marketing strategy based upon anticipated results of the marketing and legal research;

4. develop strategies DDS could use to nurture sustained, long-term consumer commitments in the postinstallation phase of its marketing plan; and

5. develop an implementation plan, timeline and proposed budget.

Graduate student discussion is animated and lively with students building off each other's strategies. The following questions have been useful for generating discussion of this case. These questions can be distributed with the case for student consideration as they prepare their analysis. As an alternative these questions can be posed by the instructor during class to generate classroom discussion. 
1. Describe how this case demonstrates the stakeholder model of the business, government, and society relationship. Describe how this case demonstrates the countervailing forces model of the business, government, and society relationship.

2. Which of the seven key environments (economic/competitive, technology, government, legal, cultural, natural and internal) are depicted in this case?

3. Who are the key stakeholders involved in, or affected by, DDS decisions and what are their central interests? What threats or opportunities do they present?

4. What is/are the major issue or issues facing DDS in this case? Do any have strategic implications? Explain.

5. What antitrust laws are relevant to DDS? Do you believe HCC has enough power to compete unfairly against DDS? Do you believe contemporary antitrust law is appropriate now that the federal government has deregulated the telecommunications and cable industries? What costs and benefits of deregulation are evident in this case?

6. What course of action should Attorney Adams take? What are her main implementation considerations?

7. What strategies should VP Smythe develop? What are his main implementation considerations?

8. Do you think the city council should grant DDS a franchise? What are the arguments for and against granting DDS a franchise?

9. What kind of competitor research does DDS need to do prior to creating a marketing plan for Huron? What type of information is needed and how would it be obtained?

10. The introduction of new products and services requires customer education. How can DDS use relationship marketing strategies to educate the customer, sell its services, and condition community opinion should the franchise grant come to a public vote?

11. If you were an HHC executive, what counter strategies might you develop?

The following teaching plan represents a module for a 50-minute class session utilizing a discussion based approach to the case.

1. Begin by asking students to describe the business, government, and society relationship concept. How is the countervailing forces model depicted? How is the stakeholder model depicted? Identify the stakeholders and their interests. (10 minutes)

2. What are the seven key environmental forces and which are relevant in this case? (5 minutes)

3. What are the legal and governmental issues faces by DDS? (5 minutes)

4. What alternative strategies might Adams adopt? What are their strengths and weaknesses? (10 minutes)

5. What is relationship marketing? What relationship marketing strategies should DDS implement? (10 minutes)

6. What roadblocks does DDS face with implementation of the legal and relationship marketing strategies? (5 minutes)

7. Wrap up of student developed strategies and discussion. Or, if the professor desires, the actions taken by DDS could be disclosed. If time permits, it is useful to discuss the costs and benefits of deregulation. (5 minutes)

\section{Discussion Of Actual Events/Epilogue}

The ensuing chronological discussion provides examples of the real world solutions adopted and used by DDS as its integrated legal and marketing strategy. Major actions, interactions and events as they actually transpired are of great interest to students and are a useful wrap up to class discussion.

The first step was gaining municipal government approval. Federal law required a cable TV provider to obtain municipal permission - a franchise - before installing its fiber optic network. While customers wanted choice, the City Commission remained skeptical. Would the company have enough money to complete the project? What kind of traffic delays and property destruction would the construction cause? How could a town this size support two cable companies? 
DDS hired a Huron native with a political background in telecommunications. She knew all the players in municipal government. She had worked on federal telecommunications legislation during 13 years as a staff member of the U.S. Senate. Her knowledge of the industry and the community was put to immediate use. A 20minute oral presentation was developed to use at a variety of community functions. With samples of old copper wire and new fiber optic cable in hand, this local DDS representative emphasized the cutting edge technology that would belong to Huron should DDS be granted a franchise.

Smythe convinced the management team that every professional interaction was viewed as an opportunity to build relationships with future DDS customer base. DDS practiced what theorists called "relational promotion" "any communication that is intended to facilitate new or fortify existing exchange relationships" (Pelton et al., 1997). Relationship marketing began with the local politicians whose approval of an operational franchise was needed before construction could begin. So, the new hire met individually with each Commissioner to explain the benefits DDS's expansion plans. Additionally, DDS agreed to comply with all federal and state laws and ensure universally available service. DDS also needed access to rights-of-way for the cable network. Huron granted this access and in exchange, DDS agreed to pay the city of Huron a percentage of the annual gross revenues. The 20minute oral presentation was also used at a series of community question and answer sessions where refreshments were also served.

DDS extended its exposure even further when it periodically sponsored community events. DDS staff participated in the community's summer festival parade. (Its competitors were nowhere in sight.) It cosponsored a golf tournament to raise funds for the high school's extracurricular activities. It hosted a Chamber of Commerce reception and inundated the crowd with DDS personnel.

An inexpensive but effective media campaign began with the news directors of all local media and their editorial boards. They, in turn, were persuaded and readily began editorializing in favor of the proposal. This public exposure - marketing before a single foot of cable had been buried - resulted in extensive public interest and excitement. Unsolicited letters to the local newspaper, complaining about current service and extolling the virtues of competition, began to appear. Testimonials to DDS's service elsewhere in southeastern South Dakota became common. Perhaps most importantly, dozens of potential customers called and asked to be put on the "waiting list" for services when available. Each contact received a packet of materials and was placed on a "potential customer" list.

Only one legal obstacle remained before the Commission would act. South Dakota law was vague on the requirements for a franchise election prior to granting a competitive cable franchise. DDS believed an opinion from the S.D. Attorney General would settle the matter. A request was submitted and at the Huron city Council's August 24 meeting, a written opinion from the Attorney General was received, stating that no public franchise election was necessary. On September 14, the Commission voted unanimously to grant the franchise. The resolution was subject to referral for 20 days. No referral petition was filed and on September 24, the franchise was officially granted and signed.

The relationship marketing strategy had succeeded at the first level. But now DDS was faced with another concern. In this case, DDS needed maximum public exposure to win the market share battle. Preannouncements of a new product or service have proven useful for this type of situation. The purpose of a preannouncement is to "secure the success of a new technology that may not have been adopted without the preannouncement" (Kohli, 1999). DDS was asking residents to change an essential service from the only provider they had ever known - a provider who, while an indifferent monopoly, did offer dependable service. DDS was offering a menu of telecommunications services, some of which had never been available before, and some of which people did not know they even needed or wanted. Businesses required time to assess their telecommunications needs. New home builders and buyers wanted to consider their options in advance of construction and purchase. DDS decided to use its preannouncements to educate potential customers, even while they increased public pressure for franchise approval. 
However, preannouncements are also valuable only "to the extent that competitive advantage can be gained" (Kohli, 1999). DDS's competitors had not reacted to DDS's presence by offering new services or better prices to their existing customers. In fact, since US West and Huron Cable did not have immediate plans to upgrade their infrastructures with high speed fiber optic cable, they were actually technically incapable of matching DDS's offer - cross-product discounts for multiple services on a single monthly bill. DDS's strategy then was to use the winter months for consumer education.

Another legal issue then arose. Customer sales forms had to request large amounts of information about the customer to meet the various legal requirements. These forms were the subject of much internal debate. And, even though the city granted DDS access to the rights-of-way, property owner easement permission was required. Ultimately it was decided to use the customer sales forms as a "pull" tactic - "a persuasive communication aimed directly at the ultimate consumer" (Pelton et al., 1997). The forms were designed to acquire all necessary information and permissions, inform customers about construction indemnification availability and, at the same time explain the multiple services and prices. This was accomplished in an attractive, concise format.

Development, integration, and implementation of DDS's marketing and legal strategies demonstrates the stakeholder and countervailing forces model of the business, government and society relationship. This case demonstrates the impact of four of the seven key environments and demonstrates the significance of the regulatory environment's impact on business.

\section{CONCLUSION}

Dakota Digital Services offers a tool to enhance student development of integrating functional areas of business by asking students to incorporate legal and relationship marketing concepts in business expansion strategizing. The case presents an actual business challenge that is intellectually stimulating for students permitting them the opportunity to utilize their critical thinking skills as they make decisions and develop strategies. By using this real situation, students gain a better understanding the importance of and how to manage local political and legal environments along with using relationship marketing tactics implemented cross-functionally.

\section{REFERENCES}

1. 1994 Congressional Quarterly Almanac, (1995). Washington, DC: Congressional Quarterly, Inc.

2. 1995 Congressional Quarterly Almanac, (1996). Washington, DC: Congressional Quarterly, Inc.

3. Brock, G.W., Katz, M.L, (June 1997). Regulation to Promote Competition: A First Look at the FCC's Implementation of the Local Competition Provisions of the Telecommunications Act of 1996. Information Economics \& Policy 9 (2), 103-117.

4. Federal Communications Commission, (June 2000). General Cable Television Industry and Regulation Information Fact Sheet. Retrieved from the World Wide Web: www.fcc/gpv/mb/facts/csgen.html.

5. Gilroy, A., (1994). Telecommunications policy reform: The telephone/cable cross-ownership debate. Washington, DC: Congressional Research Service/Library of Congress.

6. Kohli, C., (1999). Signaling New Product Introductions: A Framework Explaining the Timing of Preannouncements. Journal of Business Research 46, 45-56.

7. McIntyre, J. M., Peck, M.A., (October 1998). Managing and Measuring for Customer Loyalty: A Yin and Yang Perspective. Direct Marketing 61 (6), 48-52.

8. Pelton, L.E., Strutton, D., Lumpkin, J.R., (1997). Marketing Channels: A Relationship Management Approach. Irwin McGraw-Hill, Boston.

9. Pinto, J.K., Kharbanda, O.P., (March-April 1995). Lessons for an Accidental Profession. Business Horizons March-April, 41-50.

10. Reinke, T., (February 1998). Local Number Portability and Local Loop Competition. Telecommunications Policy 22 (1), 73-87.

11. S.D.C.L. 9-35-18, (1972). State of South Dakota.

12. Shaffer, R.A., (October 26, 1998). Small Telcos with an Entrepreneurial Edge. Fortune. 138 (8), 266-270.

13. U.S. Bureau of the Census, (2000). Census 2000: Summary File 3. www.census.gov.

14. U.S. Bureau of the Census, (2004). County Business Patterns. www.census.gov.

15. U.S. District Court for the Northern District of Texas, (December 31, 1997). SBC Communications, Inc., et al. v. Federal Communications Commission and U.S.A. CIV. A. 7:97-CV-163X. 